\title{
U.S. Department of the Interior U.S. Geological Survey \\ Effects of Land Application of Composted Biosolids on Ground Water and Native Vegetation in the New Jersey Pinelands
}

Since 1981, the State of New Jersey has required that landowners restore abandoned resource-extraction sites while protecting the integrity of Pinelands vegetation (New Jersey Administrative Code, Title 7, Chapter 50, Subchapter 6). Native vegetation in areas that have been severely disturbed by sand mining and other soil-removal operations recovers very slowly. It may be possible to accelerate the revegetation process by applying various soil amendments, such as composted sewage sludge (biosolids) and chemical fertilizers, that increase the nutrient and organic-matter content of the nutrient-poor residual subsoils at such sites. However, the potential exists for nutrients and metals to leach from these substances into ground water.

The U.S. Geological Survey (USGS), in cooperation with the New Jersey Department of Environmental Protection and Rutgers University, has established an experimental field site at the Lakehurst Naval Air Engineering Station in Lakehurst, New Jersey (fig. 1), to examine the effect of applications of composted biosolids and fertilizer to disturbed areas on ground water and to determine the ability of these substances to promote revegetation with native plants. This fact sheet describes the objectives, methods, and preliminary results of a 3-year study to determine the changes in ground water, soil, and vegetation caused by a single application of amendments in October 1995.

\section{Objectives}

- To determine whether applications of composted biosolids and chemical fertilizer will cause concentrations of dissolved metals and nutrients in ground water to increase.

- To determine which soil amendment--one of three different amounts of composted biosolids or a chemical fertilizer applied at recommended rates--is most effective in promoting revegetation of disturbed areas with native plants.

- To determine whether observed changes in ground-water quality, if any, persist or are of short duration.

\section{Study components}

- Composted biosolids and commercial fertilizer were applied once (fig. 2). The effects of the four soil amendments and of no treatment will be compared. This study design reproduces conditions likely to be encountered in actual revegetation efforts, where a single application of amendments is typical. Previous similar studies in New Jersey examined only multiple applications of liquid sludge (Kam, 1978; Higgens, 1984).

- Ground water is sampled for leached metals by using newly developed USGS "ultra-clean" methods (Ivahnenko and others, 1996), which increase the reliability of analysis results for concentrations in the parts-per-billion range. Multiscreen wells were designed to allow samples to be collected just below the water table, where leached constituents are not likely to be diluted.

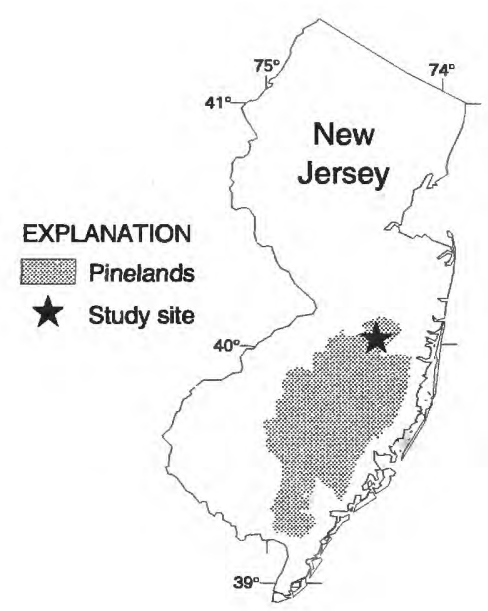

Figure 1. Location of U.S. Geological Survey biosolids study site.
- The site will be revegetated with native plants and grasses, in accordance with the current New Jersey mandate to protect the integrity of Pinelands vegetation.

- Plant growth, vegetation composition, and nitrogen mineralization rates in the soils will be documented.

\section{Soil amendments used}

- The biosolids used for this study were obtained from the Cape May County Municipal Utilities Authority sludge composting facility and meet the U.S. Environmental Protection Agency's criteria for "exceptional quality" biosolids compost (William Cathcart, Cape May County Municipal Utilities Authority, oral commun., 1996). The material was mixed with wood chips and composted.

- Commercial-grade fertilizer used was $10 \%$ nitrogen $(\mathrm{N}), 10 \%$ phosphoric acid $\left(\mathrm{P}_{2} \mathrm{O}_{5}\right)$, and $10 \%$ potash $\left(\mathrm{K}_{2} \mathrm{O}\right)$.

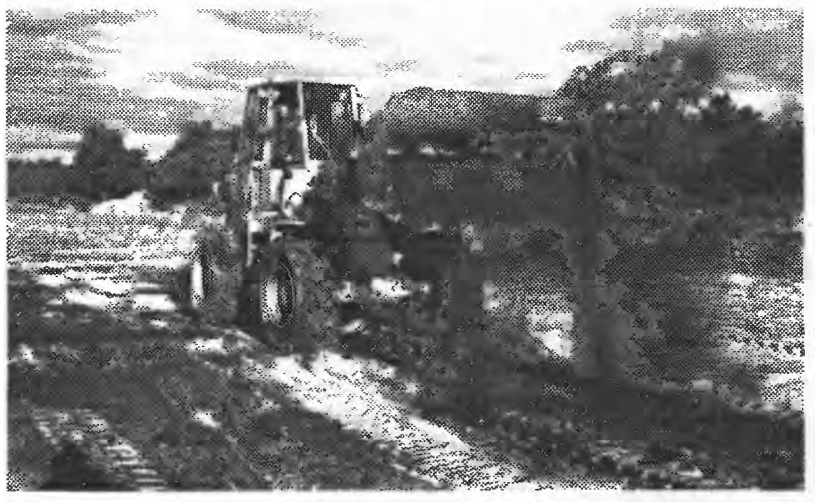

Figure 2. Application of composted biosolids to the U.S.

Geological Survey biosolids study site at the Lakehurst Naval Air Engineering Station, New Jersey, October 1995.

\section{Study methods}

- Site selection: More than 50 sites in southern New Jersey were visited and evaluated for potential use. A 4-acre site at the Lakehurst Naval Air Engineering Station was chosen for its suitable geology, depth to water, access, and security.

- Site development: Twenty-five plots were laid out in a five-byfive configuration that randomizes the location of treatments and minimizes potential variation among plots. A multiscreen well was installed at the center of each plot (fig. 3). Four additional monitoring wells were installed at the perimeter of the test site. A rainfall gage and a monitoring well equipped with a transducer were installed at the site to continuously monitor rainfall and ground-water levels. 


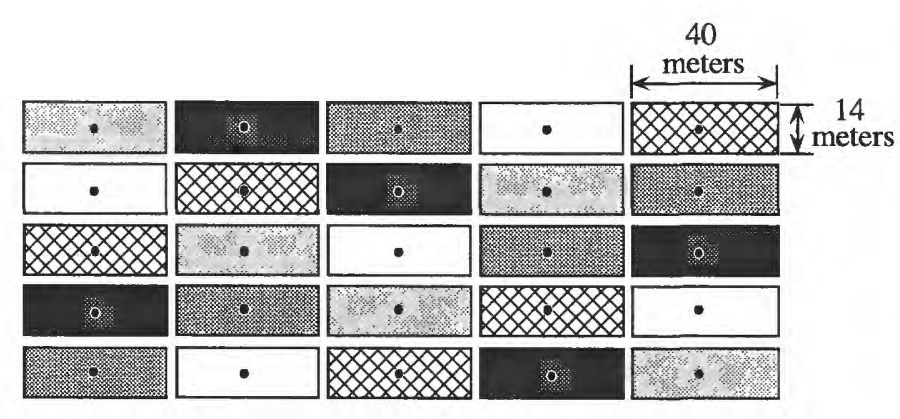

EXPLANATION

Figure 3. Plot design showing treatments and well locations at the U.S. Geological Survey biosolids study site, Lakehurst, New Jersey.

- Pre-application analyses: Soil cores collected in each plot were analyzed by Rutgers University for $\mathrm{pH}$, major cations, iron, aluminum, nutrients, trace elements, and particle size. Water in a subset of the plot wells and the perimeter wells was sampled and analyzed for metals, nutrients, and major cations and anions.

- Application of amendments: In October 1995, composted biosolids were applied to 15 of the plots at rates of 1,4 , and 8 times the vegetation nitrogen requirement (low, medium, and high rate, respectively). Commercial fertilizer was applied to five plots at the rate of 50 pounds $\mathrm{N}$ per acre. Five plots were untreated for control.

- Planting of native species: In November 1995, a mixture of pitch pine and shortleaf pine seedlings, obtained from a nearby State nursery, were planted, and the site was sown with seeds of grasses native to the Pinelands.

- Post-application monitoring: Ground-water samples will be analyzed for metals, common ions, and nitrate. Nitrogen release, plant growth, and possible invasion of exotic plant species are being evaluated. Soil cores will be collected in each plot during the third year of the study and analyzed for $\mathrm{pH}$, major cations, iron, aluminum, nutrients, trace elements, and particle size.

\section{Ground-water sampling}

- Ground-water samples are collected from the multiscreen wells in each plot shortly after recharge occurs, before the new water can disperse deeper into the system. Ground-water recharge commonly results from significant rainfall and is indicated by a rise in the water table. Water can transport leached constituents as it moves from land surface to the water table and becomes recharge. The first post-application samples were collected shortly after recharge reached the water table (fig. 4).

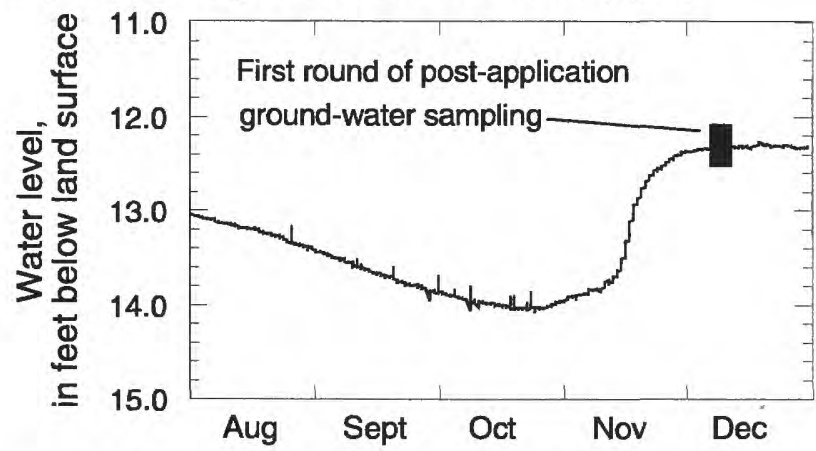

Figure 4. Ground-water levels at the U.S. Geological Survey biosolids study site, Lakehurst, New Jersey, August-December 1995.

Results of pre- and first post-application sampling

- Ground-water samples were collected and analyzed for nutrients in December 1995. Results indicate that postapplication nitrate concentrations are significantly higher than pre-application concentrations. Ground-water nitrate concentrations increased to about four to five times background concentrations ( 0.8 milligrams per liter) beneath the fertilizer plots, three to four times background concentrations beneath the compost plots, and twice background concentrations beneath the control plots (fig. 5). In the future, ground-water samples will be analyzed for nitrate and trace elements.
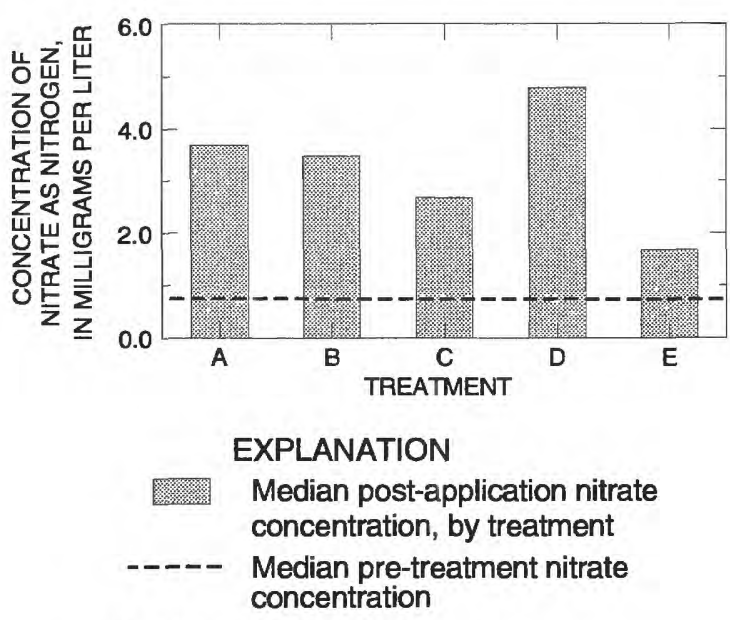

$A=$ Biosolids, low rate

$\mathrm{B}=$ Biosolids, medium rate

$\mathrm{C}=$ Biosolids, high rate

$\mathrm{D}=$ Fertilizer

$\mathrm{E}=$ Control

Figure 5. Median pre-application and median post-application concentrations of nitrate in ground water at the U.S. Geological Survey biosolids study site, Lakehurst, New Jersey.

- Eric Jacobsen

\section{References cited}

Higgens, A., 1984, Impacts on groundwater due to land application of sewage sludge: Water Resources Bulletin, v. 20 , no. 3 , p. $425-434$.

Ivahnenko, Tamara, Szabo, Zoltan., and Hall, G.S., 1996, Use of an ultra-clean sampling technique with inductively coupled plasma-mass spectrometry to determine trace-element concentrations in water from the Kirkwood-Cohansey aquifer system, Coastal Plain, New Jersey: U.S. Geological Survey Open-File Report 96-142, 37 p.

Kam, W., 1978, Effects of controlled land application of sludge on ground water quality, Ocean County, New Jersey: U.S. Geological Survey Open-File Report 78-492, 86 p.

New Jersey Administrative Code, Pinelands Management Plan: Resource extraction, Title 7, Chapter 50, Subchapter 6, 6.61-6.69.

For additional information contact:

District Chief

U.S. Geological Sunvey

810 Bear Tavern Road, Suite 206

West Trenton, New Jersey 08628 